\title{
Different effects of warming and cooling on the decomposition of soil organic matter in warm- temperate oak forests: a reciprocal translocation experiment
}

\author{
Junwei Luan · Shirong Liu · Scott X. Chang • \\ Jingxin Wang $\cdot$ Xueling Zhu $\cdot$ Kuan Liu • \\ Jianghua Wu
}

Received: 16 September 2013/Accepted: 1 August 2014/Published online: 5 September 2014

(C) The Author(s) 2014. This article is published with open access at Springerlink.com

\begin{abstract}
A reciprocal soil monolith-transfer experiment was conducted along an altitude gradient to investigate the effect of climate change on soil carbon (C) processes in two warm-temperate oak forests in Baotianman Nature Reserve, Henan Province, China. Microclimate conditions, soil surface $\mathrm{CO}_{2}$ flux, and labile organic $\mathrm{C}$ were measured for in-situ and transferred soils at both high and low-elevation sites. The soil temperature at $5 \mathrm{~cm}$ depth was, on average, $3.27{ }^{\circ} \mathrm{C}$ warmer at the low-elevation site than at the high-elevation site. Net $\mathrm{CO}_{2}$ flux $\left(911 \mathrm{~g} \mathrm{C} \mathrm{m}^{-2}\right.$
\end{abstract}

Responsible Editor: Kathleen Lohse.

J. Luan · S. Liu ( ()

The Research Institute of Forest Ecology, Environment and Protection, Chinese Academy of Forestry, Key Laboratory of Forest Ecology and Environment, China's State Forestry Administration, Beijing 100091, People's Republic of China

e-mail: liusr@caf.ac.cn

J. Luan

e-mail: junweiluan@gmail.com

J. Luan · J. Wu

Sustainable Resource management, Grenfell Campus, Memorial University of Newfoundland, Corner Brook, NL A2H 6P9, Canada

e-mail: Jwu@grenfell.mun.ca

\section{S. X. Chang}

Department of Renewable Resources, University of Alberta, Edmonton, AB T6G 2E3, Canada

e-mail: scott.chang@ualberta.ca
13 months $^{-1}, 4.7 \%$ of total C) of soil monoliths transferred from the high to the low-elevation site (simulating warming) was substantially (44\%) greater than for high-elevation soil monoliths incubated in situ $\left(633 \mathrm{~g} \mathrm{C} \mathrm{m}^{-2} 13\right.$ months $^{-1}, 3.3 \%$ of total $\mathrm{C}$ ) during 13 months of incubation. Increased extractable organic $\mathrm{C}\left(\mathrm{K}_{2} \mathrm{SO}_{4}-\mathrm{C}\right)$ supply with warming partly explained the increase of soil $\mathrm{CO}_{2}$ flux. Simulated warming also significantly increased the temperature sensitivity ( $Q_{10}$ values) of soil organic matter decomposition. The positive linear relationship between microbial metabolic quotient $\left(q \mathrm{CO}_{2}\right)$ and $Q_{10}$ suggests a connection between microbial population

\footnotetext{
J. Wang

Division of Forestry and Natural Resources, West

Virginia University, Morgantown, WV 26506, USA

e-mail: jxwang@wvu.edu

X. Zhu

Baotianman Natural Reserve Administration,

Neixiang 474350, Henan, People's Republic of China e-mail: zhubt110@hotmail.com

K. Liu

Institute for Clinical Evaluative Sciences, ELL-108, 800

Commissioners Road, London, ON N6A 5W9, Canada

e-mail: kuan.liu@ices.on.ca
} 
and $Q_{10}$ under warming conditions. Transfer of soil monoliths from the low to the high-elevation site (simulating cooling) substantially (30\%) reduced soil $\mathrm{CO}_{2}$ flux $\left(383 \mathrm{~g} \mathrm{C} \mathrm{m}^{-2} 13\right.$ months $^{-1}, 2.5 \%$ of total C) compared with those incubated in situ (550 $\mathrm{g} \mathrm{C} \mathrm{m}^{-2} 13$ months $^{-1}, 3.5 \%$ of total C). However, this was not accompanied by consistently opposite changes, to a similar extent, in labile organic $\mathrm{C}$ (microbial biomass carbon and $\mathrm{K}_{2} \mathrm{SO}_{4}-\mathrm{C}$ ) and decomposition results (i.e., $Q_{10}$ and $R_{10}$, soil respiration at $10{ }^{\circ} \mathrm{C}$ ), indicating that the soil organic matter decomposition process may not respond equally to cooling and warming. Different soil organic matter decomposition responses to cooling and warming should be considered for paleoecological modeling when both warming and cooling are involved in the changes in regional and global climates, particularly during the Holocene.

Keywords Climate warming - Simulated cooling · $\mathrm{CO}_{2}$ flux $\cdot Q_{10} \cdot$ Soil organic carbon decomposition . Microbial metabolic quotient

\section{Introduction}

The decomposition of organic matter (OM) is a fundamental global biogeochemical process, because it is important in the recycling of nutrients between soil and plant communities. Changes in the rates of OM decomposition can have profound effects on ecosystem function and productivity (Salinas et al. 2011). Because the soil carbon (C) pool is much larger than the atmospheric $\mathrm{C}$ pool, even a small change in the rate of decomposition of the large soil organic $\mathrm{C}$ pool could have a significant effect on atmospheric $\mathrm{CO}_{2}$ concentrations (Bottner et al. 2000). However, soil OM decomposition (Davidson and Janssens 2006) and microbial population size and functional group composition (Zhang et al. 2005; Zogg et al. 1997) are strongly temperature dependent. Therefore, an increase in the global mean annual temperature of $1.5-4.5^{\circ} \mathrm{C}$ over the next $50-100$ years is likely to have a substantial effect on the terrestrial ecosystem $\mathrm{C}$ cycle (IPCC 2007). Understanding the response of soil $\mathrm{OM}$ decomposition to climate change is a critical aspect of ecosystem responses to global changes (Conant et al. 2011).
A large number of warming experiments have been conducted to elucidate the effects of global warming on soil OM decomposition (Hopkins et al. 2012; Knorr et al. 2005; Luo et al. 2001; Melillo et al. 2002). However, the possibility of a cooler and wetter future climate is rarely considered in global climate change research, although rapid cooling events have occurred during the Holocene (Mayle and Cwynar 1995) and seasonal cooling is also frequently a part of the interannual variability of the climate (Brando et al. 2010; Le Barbé et al. 2002; Liang et al. 2011). It is still not clear whether or not this opposite process (i.e., cooling) will have an effect on soil OM decomposition opposite to that of warming.

Several field experimental approaches have been used to investigate potential effects of global warming on the ecosystem, for example field warming using external heat inputs (Luo et al. 2001; Melillo et al. 2002), observing differences in ecosystems along natural climatic gradients (Conant et al. 2000; Rodeghiero and Cescatti 2005), or transferring ecosystem components to a new site with different climatic conditions (Breeuwer et al. 2010; Hart 2006; Link et al. 2003; Rey et al. 2007). Especially, reciprocal treatment (simulating climate cooling) to that of warming can strengthen the conclusions drawn from warming treatment in which temperature has a dominant effect on soil-plant processes (Hart and Perry 1999). Reciprocal soil translocation experiments have been widely used to understand the potential effects of climate change on $\mathrm{C}$ and nitrogen $(\mathrm{N})$ cycles (Hart 2006; Hart and Perry 1999; Link et al. 2003; Rey et al. 2007; Zimmermann et al. 2009) and soil microbial communities (Budge et al. 2011).

The Baotianman Nature Reserve in Henan Province, China, is located in the transitional region between the northern subtropics and the warmtemperate zone. Previous research in this region revealed that the seasonality of soil temperature was the main condition affecting seasonal variation of soil $\mathrm{CO}_{2}$ flux (Luan et al. 2011a); its effect was even larger than that of soil moisture availability (Luan et al. 2012). This is a region in which the effects of climate change are expected to be substantial but the effect of warming on soil OM decomposition is poorly understood. The reserve has elevation range in excess of 1,400 meters with a $3-5{ }^{\circ} \mathrm{C}$ difference in soil temperature between low and high-elevation sites. We used the altitude gradient along the slopes of the 
Baotianman Nature Reserve to conduct a reciprocal soil monolith translocation experiment to simulate temperature changes (i.e., warming and cooling). We hypothesized that both warming and cooling (with the same extent of temperature change) will affect soil $\mathrm{CO}_{2}$ flux, labile organic $\mathrm{C}$, and decomposition behavior, and that changes in labile organic $\mathrm{C}$ could explain the effect of soil $\mathrm{CO}_{2}$ flux caused by simulated climate change. Our specific objectives were to: (1) investigate the response of soil $\mathrm{CO}_{2}$ flux to reciprocal soil monolith transfer treatments; and (2) assess how labile organic $\mathrm{C}$ and decomposition parameters (i.e., soil respiration at $10{ }^{\circ} \mathrm{C}, R_{10}$; temperature sensitivity of soil $\mathrm{OM}$ decomposition, $Q_{10}$; microbial metabolic quotient, $q \mathrm{CO}_{2}$ ) respond to simulated cooling as compared with simulated warming treatments.

\section{Materials and methods}

\section{Study sites}

Two sites (a high-elevation site and a low-elevation site) located in the Baotianman Natural Reserve in Henan Province, China, were selected to conduct the reciprocal transfer experiment. The high-elevation site $\left(33^{\circ} 29^{\prime} 51^{\prime \prime} \mathrm{N}, 111^{\circ} 55^{\prime} 58^{\prime \prime} \mathrm{E}\right)$ was located approximately 1,400 m.a.s.l., with a slope $<8 \%$. The site was occupied by secondary forest regenerated from a clear-cut harvest approximately 50 years ago, with Quercus aliena var. acuteserrata as the dominant species. In addition to the dominant species, other abundant tree species include Carpinus cordata, Cornus controversa Hemsl, and Tilia americana. Annual average precipitation and air temperature measured at a nearby weather station were $900 \mathrm{~mm}$ and $15.1^{\circ} \mathrm{C}$, respectively. Precipitation mainly falls from June to August. Soils were dominated by a Ferric Luvisols, on the basis of the FAO system of soil classification (FAO 1990). The low-elevation site $\left(33^{\circ} 28^{\prime} 55^{\prime \prime} \mathrm{N}, 111^{\circ} 52^{\prime} 52.8^{\prime \prime} \mathrm{E}\right)$ was located at approximately 620 m.a.s.l., with a slope $<10 \%$. The forest at this site was regenerated from a clear-cut harvest approximately 30 years ago. The dominant species at this site was Quercus variabilis B. Other abundant tree species include $C$. controversa Hemsl., Toxicodendron vernicifluum (Stokes) F. A. Barkl., and Quercus serrata var. brevipetiolata (A. DC.) Nakai. Annual average precipitation and air temperature were ca. $800 \mathrm{~mm}$ and $19.8^{\circ} \mathrm{C}$, respectively. Precipitation mainly occurs from
June to August. Soils were dominated by a Chromic Luvisol, on the basis of the FAO system of soil classification (FAO 1990). The basic stand attributes of the two sites are summarized in Table 1.

\section{Experimental design}

In July 2008, eight $3 \times 3 \mathrm{~m}$ plots were established randomly at both the high and low-elevation sites. Three intact soil monoliths $(30 \mathrm{~cm}$ diameter, $40 \mathrm{~cm}$ deep from the surface of the $\mathrm{O}$ horizon) were collected from adjacent locations within each plot, with the least possible disturbance, by use of PVC cylinders. The first monolith collected was returned to the laboratory for processing, the second monolith was returned to its original location within the site (in-situ soil monolith, $\mathrm{IS}_{\mathrm{HE}}$ : high-elevation soil monoliths incubated in situ; $\mathrm{IS}_{\mathrm{LE}}$ : low-elevation soil monoliths incubated in situ), and the third monolith was transferred to the other forest site for incubation (transferred soil monolith, $\mathrm{TR}_{\mathrm{H}-\mathrm{L}}$ : a soil monolith transferred from the high to the low-elevation site; $\mathrm{TR}_{\mathrm{L}-\mathrm{H}}$ : a soil monolith transferred from the low to the high-elevation site). At each site, four $1 \times 1 \mathrm{~m}$ plots trenched to $0.6 \mathrm{~m}$ depth on the perimeter were established to check on the soil coring effect (trenched). One PVC collar $(19.6 \mathrm{~cm}$ in diameter) was installed permanently in each soil monolith (centric avoiding edge effect) or trenched plot. Because one of the soil monoliths to be transferred from the low to the high-elevation site was lost during the translocation process, this experimental design had eight replicates for the high-elevation site and seven replicates for the low-elevation site, per treatment (incubated in situ or transferred) and four replicates for the trenching treatment. Vegetation (grasses and saplings) which occasionally grew in the monolith at the beginning of and during the experiment was manually removed. The soil water content of the monoliths incubated in the high-elevation site was much higher than that of those incubated in the lowelevation site. Therefore, we conducted a precipitation exclusion experiment at the high-elevation site for both the $\operatorname{IS}_{\mathrm{HE}}(n=4)$ and $\mathrm{TR}_{\mathrm{L}-\mathrm{H}}(n=3)$ treatments to further investigate the effect of soil water content on soil $\mathrm{CO}_{2}$ emission, starting from August 15, 2009. Translucent roofs, each $3 \times 3 \mathrm{~m}$, were constructed and placed $1.6 \mathrm{~m}$ above the soil monoliths to exclude the rainfall. 
Soil respiration was measured from September 2008 to November 2009, by use of an Li-8100 soil $\mathrm{CO}_{2}$ flux system (Li-Cor, Lincoln, NE, USA) for each soil monolith. Soil temperature at $5 \mathrm{~cm}$ depth from the soil surface $\left(T_{5}\right)$ was measured adjacent to each respiration collar with a portable temperature probe provided with the Li-8100. Soil volumetric water content at $0-5 \mathrm{~cm}$ depth (SWC) was measured by use of an MPKit-B portable time domain reflectometer soil moisture meter (NTZT, Nantong, China) at three points close to each collar. Measurements were made twice a month, but no measurements were made in December 2008 and January and February 2009 because the ground was covered with snow.

\section{Soil and forest stand characteristics}

Soil bulk density, organic $\mathrm{C}$, total $\mathrm{N}$, and $\mathrm{pH}$ were determined for the initial samples collected in July $2008(n=8)$. Soil bulk density every $20 \mathrm{~cm}$ for the 40-cm-long monoliths was determined by use of $100 \mathrm{~mL}$ (50.46 $\mathrm{mm}$ diameter, $50 \mathrm{~mm}$ high, $n=3$ ) sampling corers and placing intact samples in an oven at $105{ }^{\circ} \mathrm{C}$ for $24 \mathrm{~h}$ to determine soil water content. Organic $\mathrm{C}$ content was determined by the wet oxidation method with $133 \mathrm{mmol} \mathrm{L}{ }^{-1} \mathrm{~K}_{2} \mathrm{Cr}_{2} \mathrm{O}_{7}$ and digestion at $170-180{ }^{\circ} \mathrm{C}$. Soil $\mathrm{N}$ concentration was determined by a micro-Kjeldahl method (DK-152 Kjeltec Auto Analyzer; VELP, Italy) (Lu 2000).

At the end of the study period (August 29, 2010), soil samples were collected from the $0-15 \mathrm{~cm}$ layer of all monoliths, by use of a $2.54 \mathrm{~cm}$ diameter corer, to determine soil microbial biomass $\mathrm{C}$ (MBC) and $\mathrm{K}_{2} \mathrm{SO}_{4}$-extractable $\mathrm{C}\left(\mathrm{K}_{2} \mathrm{SO}_{4}-\mathrm{C}\right)$ after 13 months of treatment. Three cores were taken from each monolith and mixed to form a composite sample. The samples were kept in a cooler and delivered immediately to the laboratory for analysis. The samples were kept at $4{ }^{\circ} \mathrm{C}$ in a refrigerator before determination of $\mathrm{MBC}$ by use of the chloroform fumigation-extraction method; MBC was calculated by dividing the fumigation C-flush by a $K_{\mathrm{EC}}$ factor of 0.45 (Sparling et al. 1990). Each sample was extracted with $0.5 \mathrm{~mol} \mathrm{~L}^{-1}$ potassium sulfate $\left(\mathrm{K}_{2} \mathrm{SO}_{4}\right)$ to determine $\mathrm{K}_{2} \mathrm{SO}_{4}-\mathrm{C}$, as described by Weintraub et al. (2007).

Tree diameter at breast height (DBH) was measured $1.3 \mathrm{~m}$ from the ground for each tree in both sites. Leaf 
area index (LAI) was measured in August 2009 along a $25 \mathrm{~m}$ transect in each stand, by use of WinSCANOPY (Regent Instruments, Quebec, Canada).

Data analysis

Numerous equations have been developed to express the temperature sensitivity of respiration (Kirschbaum 2000; Janssens and Pilegaard 2003). We first used the most common expression (Davidson et al. 2006), the van't Hoff equation (Eq. 1), to describe the relationship between soil respiration $\left(R_{\mathrm{S}}\right)$ and soil temperature at $5 \mathrm{~cm}$ depth $\left(T_{5}\right)$ :

$R_{\mathrm{S}}=a e^{b T_{5}}$,

where $R_{\mathrm{S}}$ is soil respiration rate, $T_{5}$ is the soil temperature at $5 \mathrm{~cm}$ depth, $a$ and $b$ are fitted variables, and $R_{10}$ is defined as the respiration rate at $10{ }^{\circ} \mathrm{C}$. The temperature-sensitivity variable, $Q_{10}$, was calculated by use of the equation:

$Q_{10}=e^{10 b}$.

We then used the Lloyd and Taylor (1994) function:

$R_{\mathrm{S}}=a \times e^{-E_{0} /\left(T_{5}-T_{0}\right)}$,

where $a, E_{0}$, and $T_{0}$ are fitted variables, and $T_{5}$ is the soil temperature at $5 \mathrm{~cm}$ depth.

It has been suggested that this function is a better and unbiased expression of the relationship between respiration and soil temperature than the standard Arrhenius function (Fang and Moncrieff 2001) for fitting measured soil respiration rates and soil temperature data. Temperature sensitivity, as expressed by $Q_{10}$ values, was then calculated by comparing respiration rates at $5{ }^{\circ} \mathrm{C}$ above and below the site specific mean annual temperature $\left(T_{5}\right)$, as described in Zimmermann et al. (2010):

$Q_{10}=R_{T_{5+5}} / R_{T_{5-5}}$.

Soil microbial respiration (the total soil respiration reported in this study, because vegetation was excluded so there was no autotrophic respiration in our monoliths) and soil microbial biomass was used to calculate the microbial metabolic quotient $\left(q \mathrm{CO}_{2}\right)$, which is the amount of $\mathrm{CO}_{2}-\mathrm{C}$ produced per unit of microbial biomass carbon (Anderson and Domsch 1993; Wardle and Ghani 1995).
Comparisons of soil monoliths collected from the high-elevation site and incubated in situ with those transferred and incubated at the low-elevation site were made to assess the potential effects of global warming on soil pools and processes. The soil monoliths collected from the low-elevation site and incubated in situ was compared with those transferred to the high-elevation site to evaluate the simulated cooling effect on these pools and processes. Comparison of measurements made on soil monoliths incubated in situ with those made on ambient trenched soil was used to test the potential effect of soil containment on soil microclimate and on $\mathrm{CO}_{2}$ flux at each site.

A repeated-measures general linear model (GLM) was used to evaluate the effects of the treatments (ambient trenched, in situ, and transferred) on $R_{\mathrm{S}}$, SWC, and $T_{5}$. One-way analysis of variance (ANOVA) was used to evaluate the effects of the treatments (in situ, transferred) on $\mathrm{MBC}$ and $\mathrm{K}_{2} \mathrm{SO}_{4}-\mathrm{C}$ measured at the end of the study period, and $R_{10}, Q_{10}$, and $q \mathrm{CO}_{2}$ values. General linear models were used to assess the effect of soil origin, incubation site, and their interaction effects. Linear regression analysis was performed between $\mathrm{CO}_{2}$ flux (average between August 13 and September 17, 2009, which were the days closest to the soil sampling day for $\mathrm{K}_{2} \mathrm{SO}_{4}-\mathrm{C}$ and $\mathrm{MBC}$ analysis) and $\mathrm{K}_{2} \mathrm{SO}_{4}-\mathrm{C}$ and $\mathrm{MBC}$, and between $Q_{10}$ values and $q \mathrm{CO}_{2}$. All statistical analysis was performed by use of SPSS 13.0 software for Windows (SPSS, Chicago, USA).

\section{Results}

Soil micro-environment

$T_{5}$, measured at the same time as $\mathrm{CO}_{2}$ flux, was higher (a warming effect) for $\mathrm{TR}_{\mathrm{H}-\mathrm{L}}\left(\right.$ mean $=16.54{ }^{\circ} \mathrm{C}$ ) than for $\operatorname{IS}_{\mathrm{HE}}\left(13.27{ }^{\circ} \mathrm{C}\right)(P<0.01$, Fig. 1a) and lower (a cooling effect) for $\mathrm{TR}_{\mathrm{L}-\mathrm{H}}\left(13.31{ }^{\circ} \mathrm{C}\right)$ than for $\mathrm{IS}_{\mathrm{LE}}$ $\left(16.99{ }^{\circ} \mathrm{C}\right)(P<0.01$, Fig. 1b). SWC was lower for $\mathrm{TR}_{\mathrm{H}-\mathrm{L}}\left(0.23 \mathrm{~cm}^{3} \mathrm{~cm}^{-3}\right)$ than for $\operatorname{IS}_{\mathrm{HE}}\left(0.27 \mathrm{~cm}^{3}-\right.$ $\left.\mathrm{cm}^{-3}\right) \quad\left(P<0.01\right.$, Fig. 1c) but higher for $\mathrm{TR}_{\mathrm{L}-\mathrm{H}}$ $\left(0.27 \mathrm{~cm}^{3} \mathrm{~cm}^{-3}\right)$ than for $\operatorname{IS}_{\mathrm{LE}}\left(0.24 \mathrm{~cm}^{3} \mathrm{~cm}^{-3}\right)$ $(P<0.01$, Fig. 1d), indicating wetter conditions in the high-elevation site than in the low-elevation site. $T_{5}$ for trenched and in-situ treatments for both sites was no different (Fig. 1a, b), and we did not find 

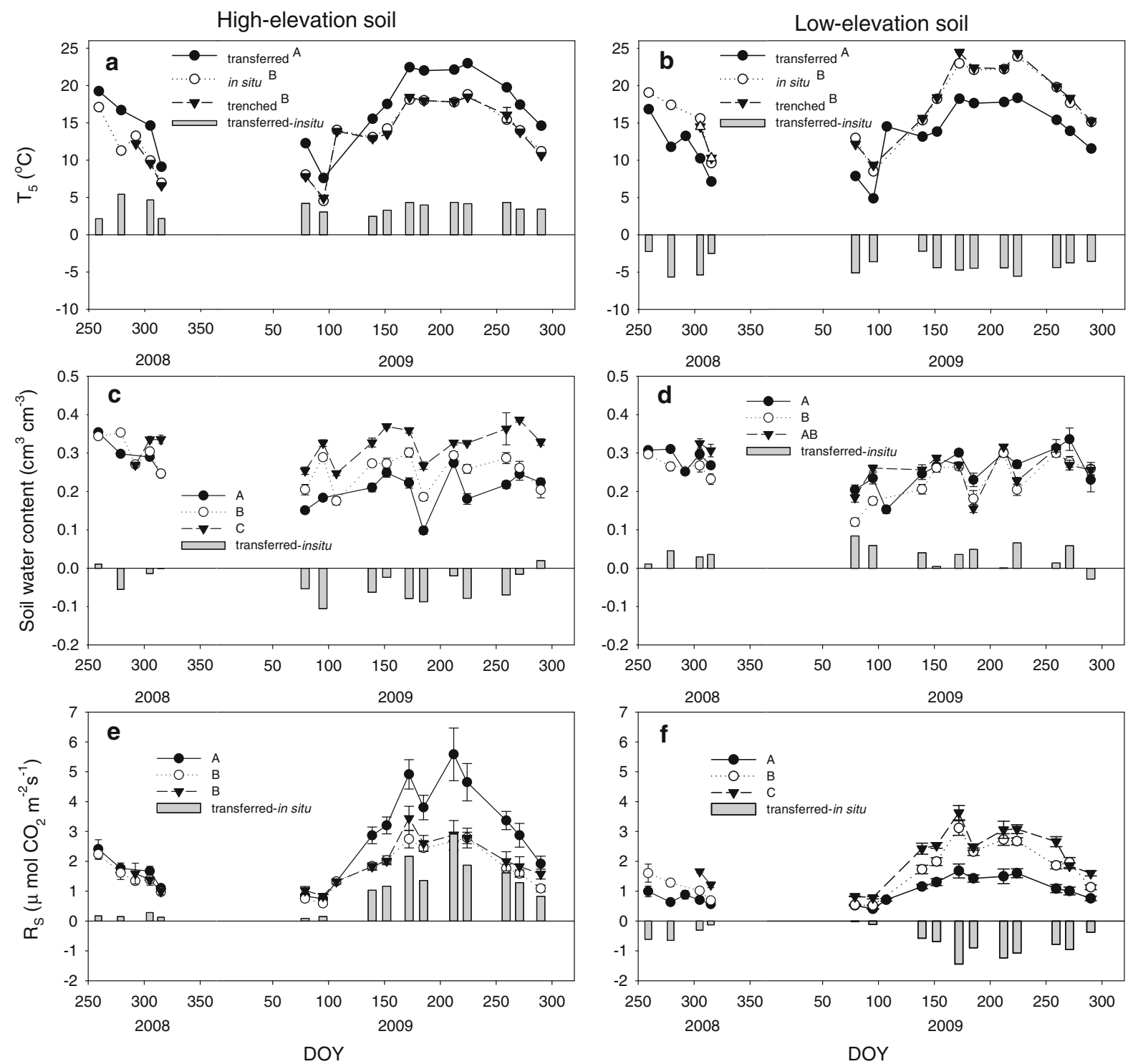

Fig. 1 Seasonal patterns of soil temperature at $5 \mathrm{~cm}$ depth $\left(T_{5}\right)$ and soil water content (SWC) among different treatments for the high and low-elevation sites. Soils were subjected to three treatments: transferred (soil monoliths incubated at the other forest site), in-situ (soil monoliths incubated in situ), and trenched (trenched to exclude root growth). The difference between transferred and in situ measurements is plotted as bars.

significant differences between SWC for in-situ and trenched treatments at the low-elevation site (Fig. 1d). No clear seasonal trend was observed for $T_{5}$ or SWC differences between the transferred and in-situ treatments for monoliths from high and low-elevation sites (Fig. 1a-d).

For a given soil sample, treatments followed by different superscript letters denote significant differences $(P<0.05)$ among treatments (RM ANOVA, Tukey's test). Vertical bars denote SE of the mean ( $n=8$ or 7 for high or low-elevation sites, respectively). Net $\mathrm{CO}_{2}$ flux from soils for e high and f lowelevation oak forest sites. Vertical bars denote SE of the mean ( $n=8$ or 7 for high or low-elevation sites, respectively)

$\mathrm{CO}_{2}$ flux

Transfer of soil monoliths from the high to the lowelevation site resulted in an increase in $\mathrm{CO}_{2}$ flux of approximately $44 \%$ over the 13-month incubation period compared with $\mathrm{IS}_{\mathrm{HE}}\left(911\right.$ and $633 \mathrm{~g} \mathrm{C} \mathrm{m}^{-2}$ 
Fig. 2 Relationships between soil $\mathrm{CO}_{2}$ flux and soil temperature at $5 \mathrm{~cm}$ depth for soil monoliths originally from a the highelevation site and $\mathbf{b}$ the low-elevation site.

Relationships between soil $\mathrm{CO}_{2}$ flux and soil water content for soil monoliths originally from $\mathbf{c}$ the highelevation site and $\mathbf{d}$ the low-elevation site
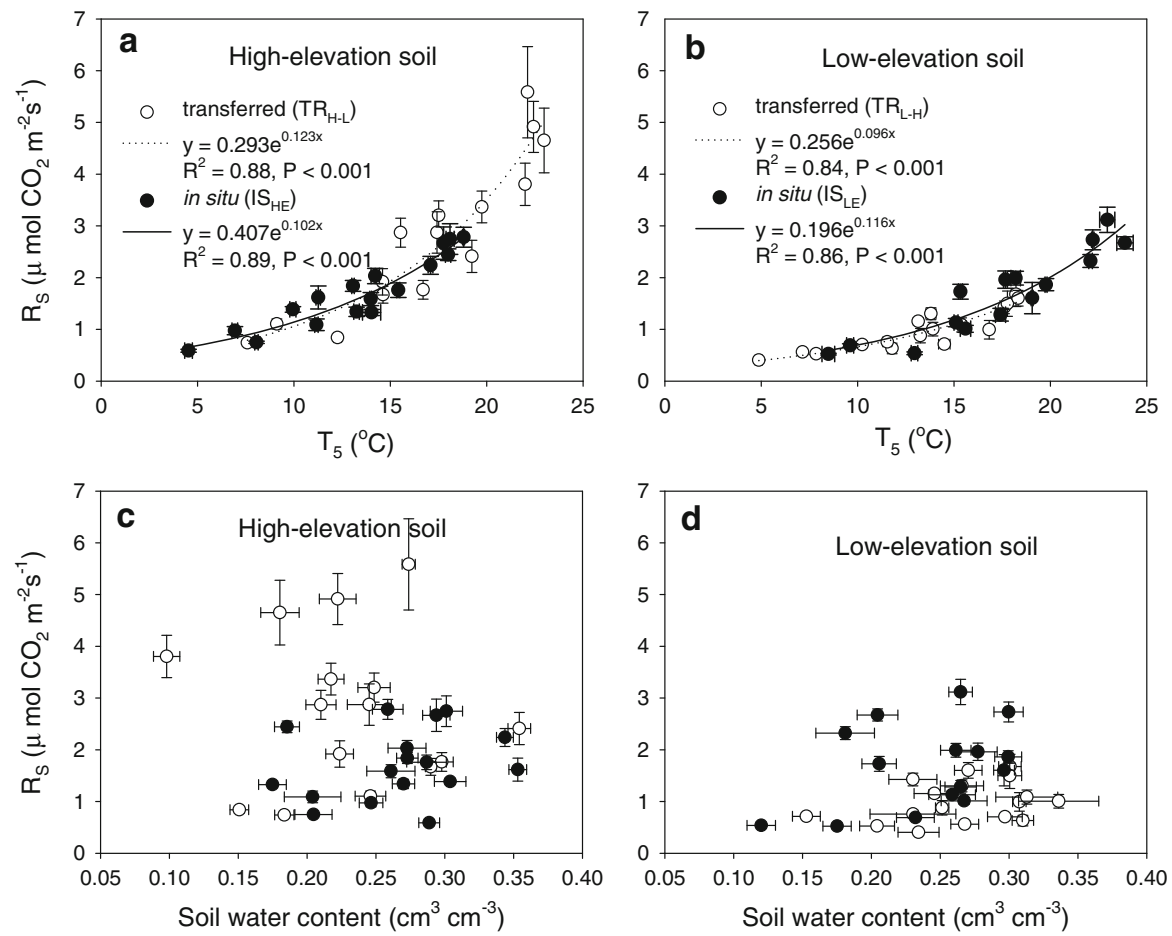

13 months $^{-1}$, respectively). Transfer of soil monoliths from the low to the high-elevation site, however, resulted in a decrease in net $\mathrm{CO}_{2}$ flux of approximately $30 \%$ compared with $\mathrm{IS}_{\mathrm{LE}}(383$ and $550 \mathrm{~g} \mathrm{C} \mathrm{m}^{-2} 13$ months $^{-1}$, respectively). Soil containment had no effect on net $\mathrm{CO}_{2}$ flux from soil monoliths at the high-elevation site, whereas a reduction was found at the low-elevation site (Fig. 1e, f). The difference between soil $\mathrm{CO}_{2}$ flux for the transferred and in-situ treatments for both the high and low-elevation sites had similar seasonal patterns to those of soil temperature (Fig. 1e, f). $T_{5}$ is a good indicator for explaining the seasonal variation of $\mathrm{CO}_{2}$ flux in the transferred and in-situ treatments for both the high and low-elevation sites $\left(R^{2}=0.84-0.89\right.$, $P<0.001$; Fig. 2a, b), whereas SWC had no relationship with seasonal variations of $\mathrm{CO}_{2}$ flux for each treatment (Fig. 2c, d). Exclusion of precipitation led to a rapid decrease of SWC and soil $\mathrm{CO}_{2}$ flux, which were significantly different between the control and the precipitation exclusion treatments (Fig. 3).

\section{Results for soil decomposition and labile organic C}

Transfer of soil monoliths from the high to the lowelevation site reduced soil $\mathrm{MBC}$ and increased $Q_{10}$ values (calculated on the basis of both the van't Hoff and Lloyd and Taylor equations), $\mathrm{K}_{2} \mathrm{SO}_{4}-\mathrm{C}$, and $q \mathrm{CO}_{2}$ compared with the $\mathrm{IS}_{\mathrm{HE}}$ treatment $(P<0.05$, Table 2). In contrast, transferring soil monoliths from the low to the high-elevation site did not affect $Q_{10}$, $\mathrm{K}_{2} \mathrm{SO}_{4}-\mathrm{C}$, and $\mathrm{MBC}$ (Table 2). Soil origin significantly affected $\mathrm{K}_{2} \mathrm{SO}_{4}-\mathrm{C}, \mathrm{MBC}$, and $R_{10}$, but not $Q_{10}$ values (calculated on the basis of both the van't Hoff and Lloyd and Taylor equations) and $q \mathrm{CO}_{2}$ (Table 3). In contrast, incubation site significantly affected $Q_{10}$, $\mathrm{MBC}$, and $q \mathrm{CO}_{2}$ (Table 3). Significant linear relationships were found between $q \mathrm{CO}_{2}$ and $Q_{10}$ values calculated by use of both the van't Hoff and Lloyd and Taylor equations (Fig. 4).

\section{Discussion}

Soil micro-environment

In our study, significant exponential relationships between soil respiration and soil temperature (Fig. 2a, b) and lack of relationships between soil respiration and soil moisture content (Fig. 2c, d) illustrate that soil temperature was the dominant factor regulating soil organic matter decomposition in the forest ecosystems 

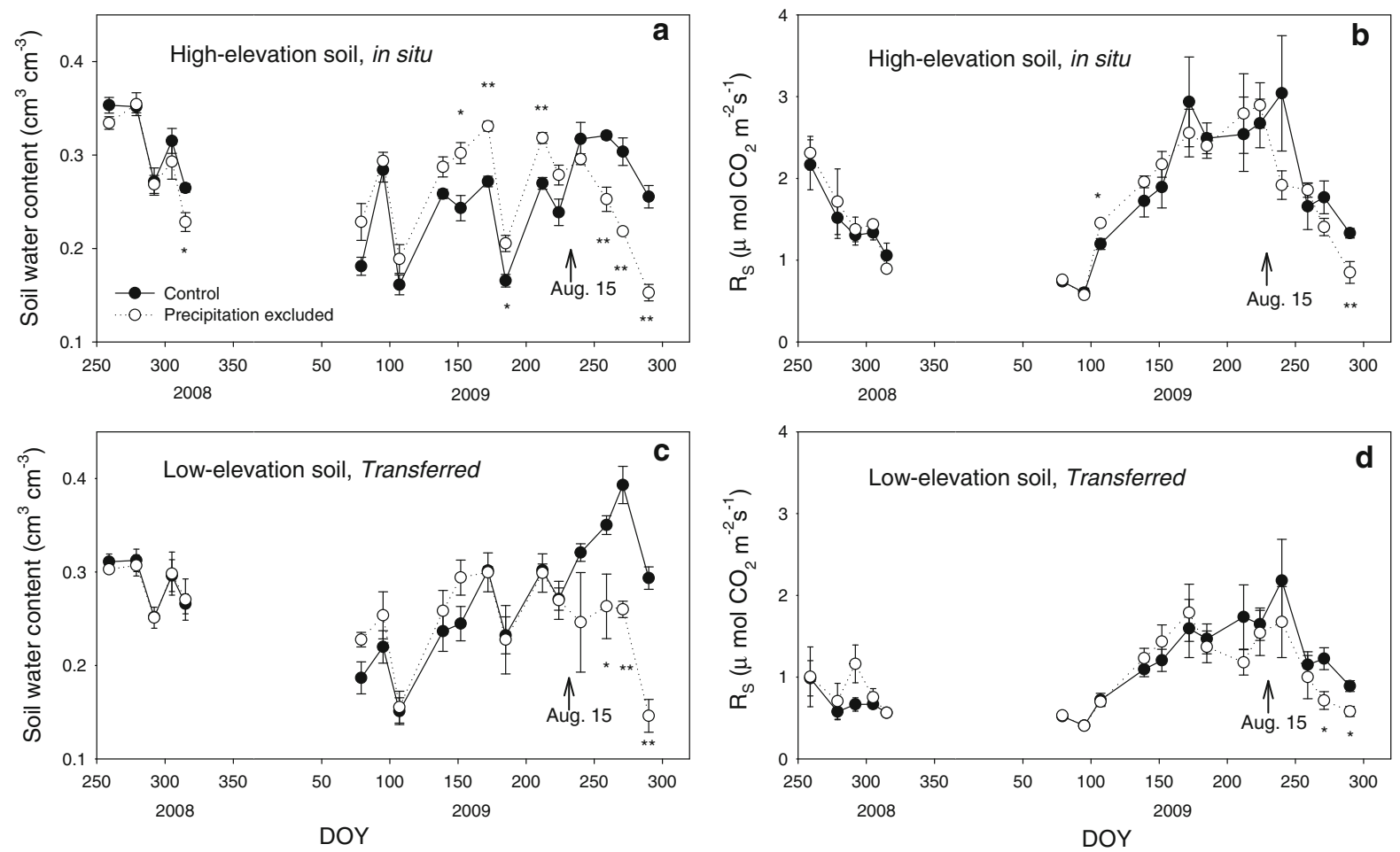

Fig. 3 Seasonal pattern of soil water content (a) and soil respiration (b) in control and precipitation exclusion treatments for high-elevation soil monoliths incubated in situ (bars denote SE of the mean, $n=4)$. Seasonal pattern of soil water content (c) and soil respiration (d) in control and precipitation exclusion

studied, similar to previous studies of those ecosystems (Luan et al. 2011a, b). Therefore, the appreciable response of soil respiration to the translocation treatment (Table 2) was mainly caused by changes in soil temperature rather than soil moisture content, even though there was a significant treatment effect on soil moisture content (Fig. 1c, d). In this study, SWC ranged between 0.15 and $0.35 \mathrm{~cm}^{3} \mathrm{~cm}^{-3}$ (except on July 4th when it dropped below $0.10 \mathrm{~cm}^{3} \mathrm{~cm}^{-3}$ ), which was likely to be within the optimum range for soil microbial activity (Luan et al. 2012). In our precipitation exclusion experiment, $\mathrm{CO}_{2}$ flux decreased after the SWC dropped to a critically low value (e.g., $0.15 \mathrm{~cm}^{3} \mathrm{~cm}^{-3}$; Fig. 3). These results further illustrate that soil temperature change had a crucial effect on responses of soil organic matter decomposition to the transfer treatment. In addition, the lack of containment effects on soil temperature in either the high or low-elevation sites indicates that we can exclude the containment effect on soil respiration

treatments for low-elevation soil monoliths incubated at the highelevation site (bars denote SE of the mean, $n=3$ ). * and ** denote significantly different SWC or $R_{\mathrm{S}}$ between the control and precipitation exclusion treatments at $P<0.05$ and $P<0.01$, respectively

from our analysis, enabling us to conduct the following more detailed analyses.

Soil $\mathrm{CO}_{2}$ flux

Our hypothesis that both warming and cooling affect soil $\mathrm{CO}_{2}$ flux is supported by the results of this study (Table 2). Soils in the high-elevation site will be vulnerable to large $\mathrm{C}$ losses under future warming conditions. Simulated warming led to $44 \%$ more C being released as $\mathrm{CO}_{2}$ whereas simulated cooling led to $30 \%$ less $\mathrm{C}$ being released as $\mathrm{CO}_{2}$ during the 13 months incubation, indicative of different effects of cooling and warming of the soils studied. Different soil characteristics between the high and low-elevation sites (Table 1) might have led to the different responses. Higher $q \mathrm{CO}_{2}$ in the warmer site (Table 2) might also explain the increase of $\mathrm{CO}_{2}$ flux, as a positive linear relationship was found between $q \mathrm{CO}_{2}$ and $\mathrm{CO}_{2}$ flux, irrespective of soil origin and incubation 
Table 2 Reciprocal soil monolith transfer effects on soil respiration rates at $10{ }^{\circ} \mathrm{C}\left(R_{10}\right), Q_{10}, \mathrm{~K}_{2} \mathrm{SO}_{4}$ extractable $\mathrm{C}$, microbial biomass $\mathrm{C}$ (MBC), and microbial metabolic quotient

\begin{tabular}{|c|c|c|c|c|c|c|c|}
\hline Soil treatment & $\begin{array}{l}\mathrm{CO}_{2} \mathrm{~g} \mathrm{C} \mathrm{m}^{-2} \\
13 \text { months }^{-1}\end{array}$ & $\begin{array}{l}R_{10} \mu \\
\mathrm{mol} \mathrm{CO}_{2} \mathrm{~m}^{-2} \mathrm{~s}^{-1}\end{array}$ & $\begin{array}{l}\text { van't } \\
\text { Hoff } \\
Q_{10}\end{array}$ & $\begin{array}{l}\text { Lloyd and } \\
\text { Taylor } Q_{10}\end{array}$ & $\begin{array}{l}\mathrm{K}_{2} \mathrm{SO}_{4} \mathrm{C} \\
\mathrm{mg} \mathrm{g}^{-1} \text { soil }\end{array}$ & $\begin{array}{l}\mathrm{MBC} \\
\mathrm{mg} \mathrm{g}^{-1} \\
\text { soil }\end{array}$ & $\begin{array}{l}q \mathrm{CO}_{2} \mu \mathrm{g} \mathrm{CO}_{2} \mathrm{~h}^{-1} \mu \mathrm{g} \\
\text { microbial } \mathrm{C}^{-1}\end{array}$ \\
\hline \multicolumn{8}{|c|}{ High-elevation soil } \\
\hline $\begin{array}{l}\text { In situ } \\
\quad\left(\mathrm{IS}_{\mathrm{HE}}\right)\end{array}$ & $633^{\mathrm{a}}(34)$ & $1.12^{\mathrm{a}}(0.05)$ & $\begin{array}{l}2.73^{\mathrm{a}} \\
\quad(0.46)\end{array}$ & $2.72^{\mathrm{a}}(0.19)$ & $0.23^{\mathrm{a}}(0.03)$ & $\begin{array}{l}1.14^{\mathrm{a}} \\
\quad(0.48)\end{array}$ & $0.010^{\mathrm{a}}(0.002)$ \\
\hline $\begin{array}{l}\text { Transferred } \\
\qquad\left(\mathrm{TR}_{\mathrm{H}-\mathrm{L}}\right)\end{array}$ & $911^{\mathrm{b}}(85)$ & $0.97^{\mathrm{a}}(0.07)$ & $\begin{array}{l}3.42^{\mathrm{b}} \\
\quad(0.48)\end{array}$ & $3.75^{\mathrm{b}}(0.33)$ & $0.27^{\mathrm{b}}(0.03)$ & $\begin{array}{l}0.73^{\mathrm{b}} \\
\quad(0.08)\end{array}$ & $0.023^{\mathrm{b}}(0.003)$ \\
\hline$F$ & 9.107 & 2.976 & 8.74 & 6.08 & 10.332 & 5.472 & 12.14 \\
\hline$P$ value & 0.009 & 0.107 & 0.01 & 0.007 & 0.006 & 0.035 & 0.004 \\
\hline \multicolumn{8}{|c|}{ Low-elevation soil } \\
\hline $\begin{array}{l}\text { In situ } \\
\quad\left(\mathrm{IS}_{\mathrm{LE}}\right)\end{array}$ & $550^{\mathrm{a}}(23)$ & $0.61^{\mathrm{a}}(0.03)$ & $\begin{array}{l}3.10^{\mathrm{a}} \\
\quad(0.28)\end{array}$ & $3.31^{\mathrm{a}}(0.11)$ & $0.09^{\mathrm{a}}(0.04)$ & $\begin{array}{l}0.40^{\mathrm{a}} \\
\quad(0.21)\end{array}$ & $0.019^{\mathrm{a}}(0.003)$ \\
\hline $\begin{array}{l}\text { Transferred } \\
\left(\mathrm{TR}_{\mathrm{L}-\mathrm{H}}\right)\end{array}$ & $383^{\mathrm{b}}(23)$ & $0.54^{\mathrm{a}}(0.06)$ & $\begin{array}{l}2.69^{\mathrm{a}} \\
\quad(0.65)\end{array}$ & $3.03^{\mathrm{a}}(0.42)$ & $0.10^{\mathrm{a}}(0.04)$ & $\begin{array}{l}0.59^{\mathrm{a}} \\
\quad(0.19)\end{array}$ & $0.0065^{\mathrm{b}}(0.0006)$ \\
\hline$F$ & 22.43 & 1.215 & 2.278 & 0.429 & 0.109 & 3.348 & 16.32 \\
\hline$P$ value & $<0.001$ & 0.292 & 0.157 & 0.525 & 0.746 & 0.092 & 0.002 \\
\hline
\end{tabular}

$\mathrm{IS}_{\mathrm{HE}}$, high-elevation soil monoliths incubated in situ; $\mathrm{IS}_{\mathrm{LE}}$, low-elevation soil monoliths incubated in situ; TR $\mathrm{H}_{\mathrm{L}}$, high-elevation soil monoliths transferred to the low-elevation site; $\mathrm{TR}_{\mathrm{L}-\mathrm{H}}$, low-elevation soil monoliths transferred to the high-elevation site

Values in parentheses are SE. Different lowercase letters within each column indicate significant difference at $P=0.05$ level

site $\left(\mathrm{CO}_{2}\right.$ flux $=399.6+14081 \times q \mathrm{CO}_{2}, R^{2}=0.33$, $P=0.001)$.

Interestingly, $\mathrm{CO}_{2}$ flux rates were similar for the two soils in their initial elevations even though there were apparent differences in soil characteristics (i.e., lower SOC, $\mathrm{K}_{2} \mathrm{SO}_{4}-\mathrm{C}$ and $\mathrm{MBC}$ at the low-elevation site, Table 2). In addition, if we do not consider the direction of soil monolith transfer, both high and lowelevation soils had $44 \%$ greater $\mathrm{CO}_{2}$ flux when they were incubated in the low-elevation site than those incubated in the high-elevation site, indicating that the temperature difference between the two sites determined the different $\mathrm{CO}_{2}$ flux rates. In combination with higher soil $\mathrm{C}$ stock at the higher-elevation site (Table 1), similar $\mathrm{CO}_{2}$ flux rate between both soils incubated in situ implies that more $\mathrm{C}$ would be stored in the soil at the high-elevation site (Zimmermann et al. 2009, 2010).

Soil heterotrophic respiration is determined by temperature and many other factors other than temperature, for example C substrate supply, microbial biomass, and climatic conditions (Davidson et al. 2006). In our study, a $3.27{ }^{\circ} \mathrm{C}$ soil temperature increase led to a $44 \%$ increase in soil $\mathrm{CO}_{2}$ flux, which was much less than the $120 \%$ increase reported $\left(q \mathrm{CO}_{2}\right)$ of the high and low-elevation sites in Baotianman National Nature Reserve 

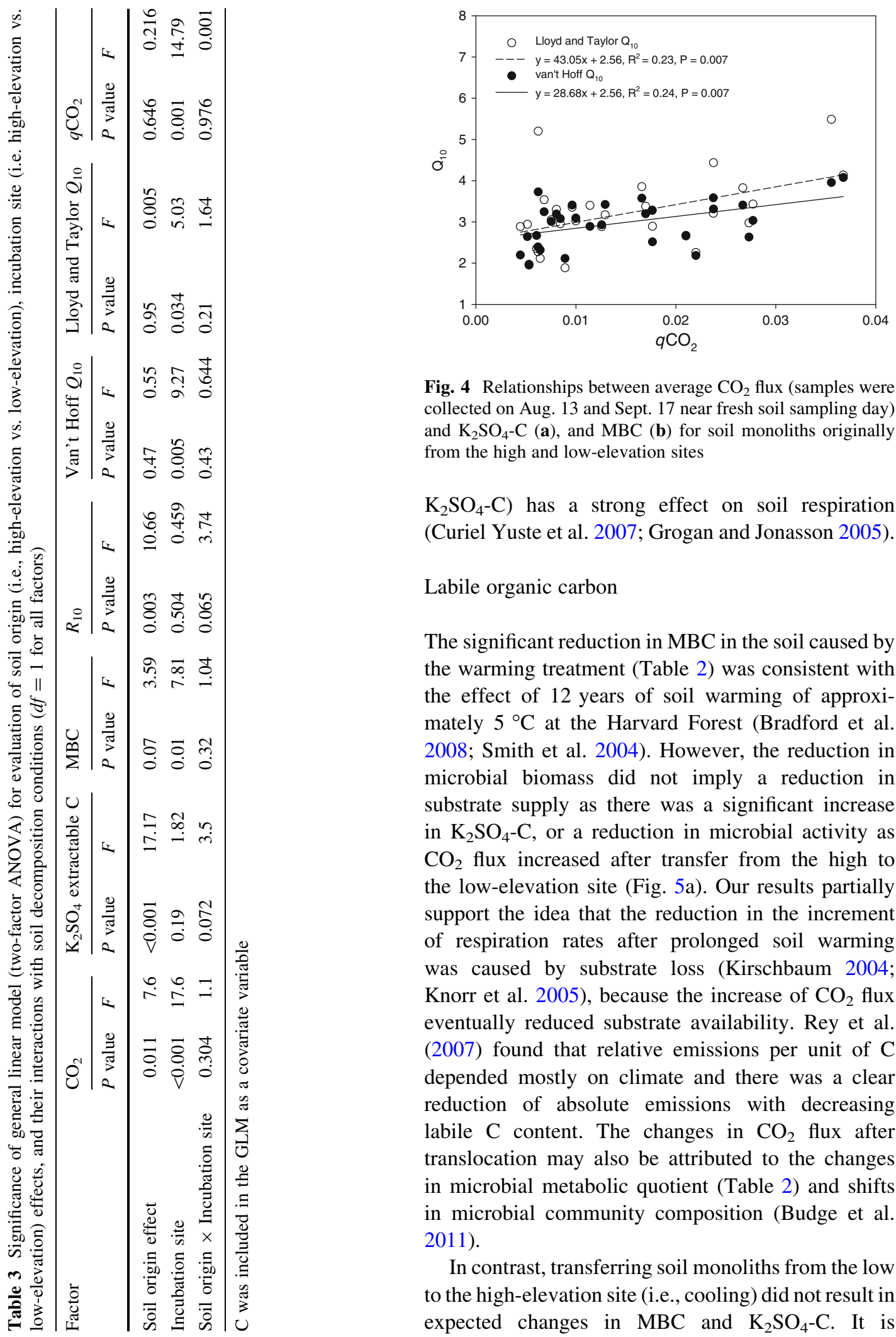

Fig. 4 Relationships between average $\mathrm{CO}_{2}$ flux (samples were collected on Aug. 13 and Sept. 17 near fresh soil sampling day) and $\mathrm{K}_{2} \mathrm{SO}_{4}-\mathrm{C}$ (a), and $\mathrm{MBC}$ (b) for soil monoliths originally from the high and low-elevation sites

$\left.\mathrm{K}_{2} \mathrm{SO}_{4}-\mathrm{C}\right)$ has a strong effect on soil respiration (Curiel Yuste et al. 2007; Grogan and Jonasson 2005).

Labile organic carbon

The significant reduction in MBC in the soil caused by the warming treatment (Table 2) was consistent with the effect of 12 years of soil warming of approximately $5{ }^{\circ} \mathrm{C}$ at the Harvard Forest (Bradford et al. 2008; Smith et al. 2004). However, the reduction in microbial biomass did not imply a reduction in substrate supply as there was a significant increase in $\mathrm{K}_{2} \mathrm{SO}_{4}-\mathrm{C}$, or a reduction in microbial activity as $\mathrm{CO}_{2}$ flux increased after transfer from the high to the low-elevation site (Fig. 5a). Our results partially support the idea that the reduction in the increment of respiration rates after prolonged soil warming was caused by substrate loss (Kirschbaum 2004; Knorr et al. 2005), because the increase of $\mathrm{CO}_{2}$ flux eventually reduced substrate availability. Rey et al. (2007) found that relative emissions per unit of C depended mostly on climate and there was a clear reduction of absolute emissions with decreasing labile $\mathrm{C}$ content. The changes in $\mathrm{CO}_{2}$ flux after translocation may also be attributed to the changes in microbial metabolic quotient (Table 2) and shifts in microbial community composition (Budge et al. 2011).

In contrast, transferring soil monoliths from the low to the high-elevation site (i.e., cooling) did not result in expected changes in $\mathrm{MBC}$ and $\mathrm{K}_{2} \mathrm{SO}_{4}$-C. It is 
Fig. 5 Relationships between $q \mathrm{CO}_{2}$ and $Q_{10}$ values calculated on the basis of both the van't Hoff and Lloyd and Taylor equations
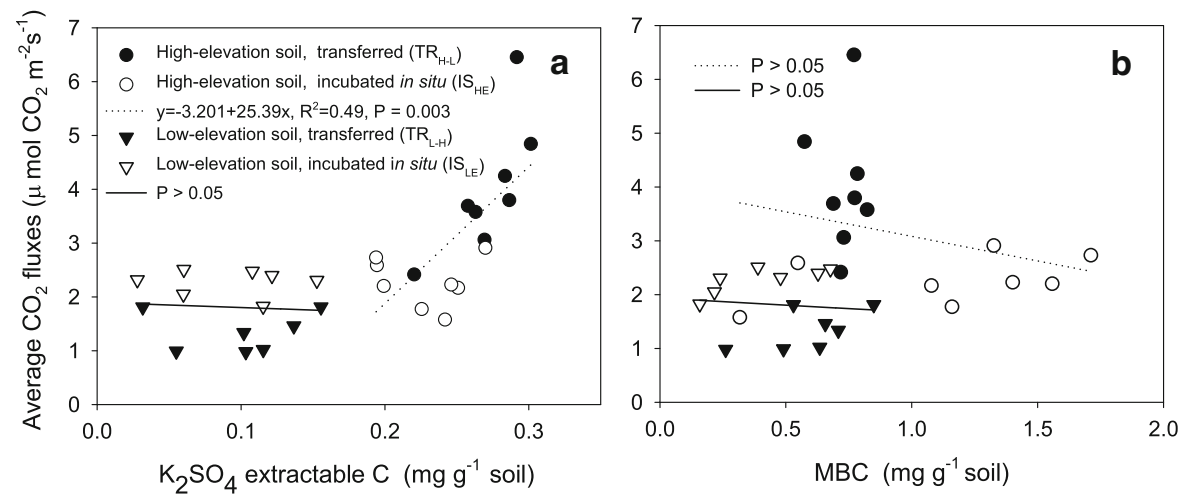

plausible that soils from the low-elevation site with poor labile-C and a smaller microbial population, were less responsive to the change in temperature, and required a longer time to adapt to the new (cooler) environment. We found that neither $\mathrm{MBC}$ nor $\mathrm{K}_{2} \mathrm{SO}_{4}$ $\mathrm{C}$ could explain the reduction of $\mathrm{CO}_{2}$ flux after transferring soil monoliths from the low to the highelevation site (Fig. 5a, b). Therefore, only part of our hypothesis was supported-that warming will affect labile organic $\mathrm{C}$ and subsequently $\mathrm{CO}_{2}$ flux; however, the corresponding responses did not occur in the cooling treatment, rejecting part of the hypothesis.

\section{Temperature sensitivity of soil respiration}

$Q_{10}$ values increased when soil monoliths were transferred from the high to the low-elevation site (Table 2) and were affected by incubation site but not by soil origin (Table 3 ), indicating a higher risk of $\mathrm{C}$ loss under future warming conditions. We found a significant linear relationship between $Q_{10}$ values and $q \mathrm{CO}_{2}$ (Fig. 4), suggesting a connection between temperature sensitivity of soil organic matter decomposition and soil microbial function under warming, because $q \mathrm{CO}_{2}$ is a useful measure of microbial efficiency in conserving C (Wardle and Ghani 1995). Soil microbes that were adapted to the higher elevation (lower temperature) reduced their biomass and increased $q \mathrm{CO}_{2}$ when the soil was transferred to the lower-elevation (higher-temperature) site. A moderate shift of microbial communities toward new environmental conditions 11 years after soil translocation was observed by Budge et al. (2011). The increased $Q_{10}$ values with warming might also be linked to the greater amount of respired biochemically recalcitrant
SOM, which has greater temperature sensitivity (Craine et al. 2010). It was very likely that labile C would drastically decline at the end of the warming experiment, forcing microbes to rely on more recalcitrant soil $\mathrm{C}$.

In contrast, $Q_{10}$ and $R_{10}$ were not affected by transferring soil monoliths from the low to the highelevation site (Table 2), suggesting that the temperature reduction might be within the range of tolerance limits for normal microbial activity, or the phenomenon represented a chronic response (or acclimation, adaptation) of microbial community to cooling. The fact that soils from the high and low-elevation sites differ in their properties, for example soil $\mathrm{C}$ and $\mathrm{N}$ content, could also cause the different warming and cooling effects observed. However, we did not find significant effect of soil origin on both $Q_{10}$ and $q \mathrm{CO}_{2}$ (Table 3 ). Therefore, $Q_{10}$ was mainly affected by transfer of the soils. Although different methods used to calculate $Q_{10}$ might lead to different results (Zimmermann et al. 2009), $Q_{10}$ calculated by use of both the van't Hoff (the most commonly used equation) and the Lloyd and Taylor (suggested to give an unbiased estimate of $Q_{10}$ ) equations had consistent responses to the treatments in our study.

The $Q_{10}$ calculation can be affected by the range of temperature considered (Kätterer et al. 1998; PazFerreiro et al. 2012). However, the positive warming effect on $Q_{10}$ in our study was apparently not caused by the different temperature range, because lower temperature sensitivity were estimated at higher temperatures (Kätterer et al. 1998). The positive warming effects on $Q_{10}$ values must be further studied, because this translocation experiment was conducted for one year only. It is reported that a sustained temperature increase may reduce the 
temperature sensitivity of soil OM decomposition (Craine et al. 2013). Therefore, the response of soil OM decomposition to warming might be a nonlinear process, along with depletion of soil labile carbon (Bradford et al. 2008) and the adaptation of microbes to the new environment (Bradford et al. 2008; Crowther and Bradford 2013; Luo et al. 2001). The acclimation or adaptation of microbes to warming has been widely reported (Luo et al. 2001; Bradford et al. 2008), and it is important to understand microbial response to cooling, with implications for modeling of paleoclimate (e.g., Holocene), particularly during periods of regional or global cooling. Further research is needed to broaden our understanding of possible mechanisms causing different responses to cooling and warming.

\section{Conclusions}

The simulated warming treatment (transfer of soils from the high to the low-elevation site) altered soil OM decomposition processes, including increased soil surface $\mathrm{CO}_{2}$ flux and labile organic $\mathrm{C}$ (i.e., $\mathrm{K}_{2} \mathrm{SO}_{4}-\mathrm{C}$ ) production. Therefore, a large amount of soil $\mathrm{C}$ loss occurred in the early stage of warming and such $\mathrm{C}$ losses were linked to the increased extractable organic $\mathrm{C}\left(\mathrm{K}_{2} \mathrm{SO}_{4}-\mathrm{C}\right)$ supply under warming. The simulated cooling reduced $\mathrm{CO}_{2}$ flux, but the extent of decrease in $\mathrm{C}$ loss $(30 \%)$ was lower than the extent of increase in $\mathrm{C}$ loss (44\%) caused by simulated warming. Furthermore, cooling did not cause the expected opposite changes in labile organic $\mathrm{C}$ and decomposition behavior. We therefore conclude that cooling and warming had different effects on soil organic C processes. Such different effects should be taken into consideration in paleoecological modeling when both warming and cooling are involved in changes in the regional and global climate.

Acknowledgments We gratefully acknowledge the support of Yin Wu, Ye Tian, Xinfang Yang, Xiaojing Liu, Song Yao, and Jiguo Liu of the Baotianman National Nature Reserve for their assistance in field monitoring and sampling. We are grateful to professor $\mathrm{Pu} \mathrm{Mu}$ of Beijing Normal University and the three anonymous reviewers for their valuable comments on an earlier version of the manuscript. This study was jointly funded by China's National Natural Science Foundation (No. 31290223), the Ministry of Finance (No. 201104006, 201404201), the Ministry of Science and Technology (2012BAD22B01), and CFERN and GENE Award Funds on Ecological Paper.
Open Access This article is distributed under the terms of the Creative Commons Attribution License which permits any use, distribution, and reproduction in any medium, provided the original author(s) and the source are credited.

\section{References}

Anderson T-H, Domsch KH (1993) The metabolic quotient for $\mathrm{CO}_{2}\left(q \mathrm{CO}_{2}\right)$ as a specific activity parameter to assess the effects of environmental conditions, such as $\mathrm{pH}$, on the microbial biomass of forest soils. Soil Biol Biochem 25(3):393-395

Bottner P, Couteaux M-M, Anderson JM, Berg B, Billes G, Bolger T, Casabianca H, Romanya J, Rovira P (2000) Decomposition of ${ }^{13} \mathrm{C}$-labelled plant material in a European $65-40^{\circ}$ latitudinal transect of coniferous forest soils: simulation of climate change by translocation of soils. Soil Biol Biochem 32(4):527-543

Bradford MA, Davies CA, Frey SD, Maddox TR, Melillo JM, Mohan JE, Reynolds JF, Treseder KK, Wallenstein MD (2008) Thermal adaptation of soil microbial respiration to elevated temperature. Ecol Lett 11(12):1316-1327

Brando PM, Goetz SJ, Baccini A, Nepstad DC, Beck PSA, Christman MC (2010) Seasonal and interannual variability of climate and vegetation indices across the Amazon. Proc Natl Acad Sci USA 107:14685-14690

Breeuwer A, Heijmans M, Robroek B, Berendse F (2010) Field simulation of global change: transplanting northern bog mesocosms southward. Ecosystems 13(5):712-726

Budge K, Leifeld J, Egli M, Fuhrer J (2011) Soil microbial communities in (sub)alpine grasslands indicate a moderate shift towards new environmental conditions 11 years after soil translocation. Soil Biol Biochem 43(6):1148-1154

Conant RT, Klopatek JM, Klopatek CC (2000) Environmental factors controlling soil respiration in three semiarid ecosystems. Soil Sci Soc Am J 64(1):383-390

Conant RT, Ryan MG, Ågren GI, Birge HE, Davidson EA, Eliasson PE, Evans SE, Frey SD, Giardina CP, Hopkins FM, Hyvönen R, Kirschbaum MUF, Lavallee JM, Leifeld J, Parton WJ, Megan Steinweg J, Wallenstein MD, Martin Wetterstedt JA, Bradford MA (2011) Temperature and soil organic matter decomposition rates-synthesis of current knowledge and a way forward. Glob Change Biol 17(11):3392-3404

Craine J, Fierer N, McLauchlan K, Elmore A (2013) Reduction of the temperature sensitivity of soil organic matter decomposition with sustained temperature increase. Biogeochemistry 113(1-3):359-368

Craine JM, Fierer N, McLauchlan KK (2010) Widespread coupling between the rate and temperature sensitivity of organic matter decay. Nat Geosci 3(12):854-857

Crowther TW, Bradford MA (2013) Thermal acclimation in widespread heterotrophic soil microbes. Ecol Lett 16(4):469-477

Curiel Yuste J, Baldocchi DD, Gershenson A, Goldstein A, Misson L, Wong S (2007) Microbial soil respiration and its dependency on carbon inputs, soil temperature and moisture. Glob Change Biol 13(9):2018-2035 
Davidson EA, Janssens IA (2006) Temperature sensitivity of soil carbon decomposition and feedbacks to climate change. Nature 440:165-173

Davidson EA, Janssens IA, Luo Y (2006) On the variability of respiration in terrestrial ecosystems: moving beyond $Q_{10}$. Glob Change Biol 12(2):154-164

Fang C, Moncrieff JB (2001) The dependence of soil $\mathrm{CO}_{2}$ efflux on temperature. Soil Biol Biochem 33(2):155-165

FAO (1990) FAO-UNESCO Soil Map of the World, vol VIII. FAO, Paris

Grogan P, Jonasson S (2005) Temperature and substrate controls on intra-annual variation in ecosystem respiration in two subarctic vegetation types. Glob Change Biol 11(3):465-475

Hart SC (2006) Potential impacts of climate change on nitrogen transformations and greenhouse gas fluxes in forests: a soil transfer study. Glob Change Biol 12(6):1032-1046

Hart SC, Perry DA (1999) Transferring soils from high- to lowelevation forests increases nitrogen cycling rates: climate change implications. Glob Change Biol 5(1):23-32

Hopkins FM, Torn MS, Trumbore SE (2012) Warming accelerates decomposition of decades-old carbon in forest soils. Proc Natl Acad Sci USA 109(26):E1753-E1761. doi:10. 1073/pnas.1120603109

IPCC (2007) Summary for policymakers. In: Solomon S, Qin D, Manning M, Chen Z, Marquis M, Averyt KB, Tignor M, Miller HL (eds) Climate change 2007: The physical science basis. Contribution of working group I to the fourth assessment report of the Intergovernmental panel on climate change, Cambridge university press, Cambridge, New York

Janssens IA, Pilegaard KIM (2003) Large seasonal changes in $Q_{10}$ of soil respiration in a beech forest. Glob Change Biol 9(6):911-918

Kätterer T, Reichstein M, Andrén O, Lomander A (1998) Temperature dependence of organic matter decomposition: a critical review using literature data analyzed with different models. Biol Fertil Soils 27(3):258-262

Kirschbaum MUF (2000) Will changes in soil organic carbon act as a positive or negative feedback on global warming? Biogeochemistry 48:21-51

Kirschbaum MUF (2004) Soil respiration under prolonged soil warming: are rate reductions caused by acclimation or substrate loss? Glob Change Biol 10(11):1870-1877

Knorr W, Prentice IC, House JI, Holland EA (2005) Long-term sensitivity of soil carbon turnover to warming. Nature 433(7023):298-301

Le Barbé L, Lebel T, Tapsoba D (2002) Rainfall variability in West Africa during the Years 1950-90. J Clim 15(2): 187-202

Liang CK, Eldering A, Gettelman A, Tian B, Wong S, Fetzer EJ, Liou KN (2011) Record of tropical interannual variability of temperature and water vapor from a combined AIRSMLS data set. J Geophys Res 116:D06103

Link SO, Smith JL, Halvorson JJ, Bolton H (2003) A reciprocal transplant experiment within a climatic gradient in a semiarid shrub-steppe ecosystem: effects on bunchgrass growth and reproduction, soil carbon, and soil nitrogen. Glob Change Biol 9(7):1097-1105

Lloyd J, Taylor JA (1994) On the temperature dependence of soil respiration. Funct Ecol 8:315-323
Lu R (2000) Soil and agricultural chemistry analysis methods (in chinese). Chinese Agricultural Scientific and Technology Press, Beijing

Luan J, Liu S, Wang J, Zhu X, Shi Z (2011a) Rhizospheric and heterotrophic respiration of a warm-temperate oak chronosequence in China. Soil Biol Biochem 43(3):503-512

Luan J, Liu S, Zhu X, Wang J (2011b) Soil carbon stocks and fluxes in a warm-temperate oak chronosequence in China. Plant Soil 347(1):243-253

Luan J, Liu S, Zhu X, Wang J, Liu K (2012) Roles of biotic and abiotic variables in determining spatial variation of soil respiration in secondary oak and planted pine forests. Soil Biol Biochem 44(1):143-150

Luo Y, Wan S, Hui D, Wallace LL (2001) Acclimatization of soil respiration to warming in a tall grass prairie. Nature 413(6856):622-625

Martin JG, Bolstad PV (2005) Annual soil respiration in broadleaf forests of northern Wisconsin: influence of moisture and site biological, chemical, and physical characteristics. Biogeochemistry 73(1):149-182

Mayle FE, Cwynar LC (1995) Impact of the younger dryas cooling event upon lowland vegetation of maritime Canada. Ecol Monogr 65(2):129-154

Melillo JM, Steudler PA, Aber JD, Newkirk K, Lux H, Bowles FP, Catricala C, Magill A, Ahrens T, Morrisseau S (2002) Soil warming and carbon-cycle feedbacks to the climate system. Science 298(5601):2173-2176

Paz-Ferreiro J, Medina-Roldán E, Ostle NJ, McNamara NP, Bardgett RD (2012) Grazing increases the temperature sensitivity of soil organic matter decomposition in a temperate grassland. Environ Res Lett 7(1):014027

Rey M, Guntinas E, Gil-Sotres F, LeirOs MC, Trasar-Cepeda C (2007) Translocation of soils to stimulate climate change: $\mathrm{CO}_{2}$ emissions and modifications to soil organic matter. Eur J Soil Sci 58(6):1233-1243

Rodeghiero M, Cescatti A (2005) Main determinants of forest soil respiration along an elevation/temperature gradient in the Italian Alps. Glob Change Biol 11(7):1024-1041

Salinas N, Malhi Y, Meir P, Silman M, Roman Cuesta R, Huaman J, Salinas D, Huaman V, Gibaja A, Mamani M, Farfan F (2011) The sensitivity of tropical leaf litter decomposition to temperature: results from a large-scale leaf translocation experiment along an elevation gradient in Peruvian forests. New phytol 189(4):967-977

Smith H, Frey S, Knorr M (2004) Microbial responses to soil warming: Harvard University LTER and NIGEC Programs. In: Abstracts from the 15th annual harvard forest ecology symposium

Sparling GP, Feltham CW, Reynolds J, West AW, Singleton P (1990) Estimation of soil microbial c by a fumigationextraction method: use on soils of high organic matter content, and a reassessment of the kec-factor. Soil Biol Biochem 22(3):301-307

Wardle DA, Ghani A (1995) A critique of the microbial metabolic quotient $\left(q \mathrm{CO}_{2}\right)$ as a bioindicator of disturbance and ecosystem development. Soil Biol Biochem 27(12): 1601-1610

Weintraub M, Scott-Denton L, Schmidt S, Monson R (2007) The effects of tree rhizodeposition on soil exoenzyme activity, dissolved organic carbon, and nutrient availability 
in a subalpine forest ecosystem. Oecologia 154(2): 327-338

Zhang W, Parker KM, Luo Y, Wan S, Wallace LL, Hu S (2005) Soil microbial responses to experimental warming and clipping in a tallgrass prairie. Glob Change Biol 11(2):266-277

Zimmermann M, Meir P, Bird MI, Malhi Y, Ccahuana AJQ (2009) Climate dependence of heterotrophic soil respiration from a soil-translocation experiment along a $3000 \mathrm{~m}$ tropical forest altitudinal gradient. Eur J Soil Sci 60(6):895-906
Zimmermann M, Meir P, Bird MI, Malhi Y, Ccahuana AJQ (2010) Temporal variation and climate dependence of soil respiration and its components along a $3,000 \mathrm{~m}$ altitudinal tropical forest gradient. Glob Biogeochem Cycles 24(4):GB4012

Zogg GP, Zak DR, Ringelberg DB, MacDonald NW, Pregitzer KS, White DC (1997) Compositional and functional shifts in microbial communities due to soil warming. Soil Sci Soc Am J 61:475-481 